1989

\title{
The Three 'Rs': Reading/Rorty/Radically
}

Allan C. Hutchinson

Osgoode Hall Law School of York University, ahutchinson@osgoode.yorku.ca

Source Publication:

Harvard Law Review. Volume 103, Issue 2 (1989), p. 555-585.

Follow this and additional works at: https://digitalcommons.osgoode.yorku.ca/scholarly_works (c) $(i) \Theta(9$

This work is licensed under a Creative Commons Attribution-Noncommercial-No Derivative Works 4.0 License.

Recommended Citation

Hutchinson, Allan C. "The Three 'Rs': Reading/Rorty/Radically." Harvard Law Review 103.2 (1989): 555-585.

This Book Review is brought to you for free and open access by the Faculty Scholarship at Osgoode Digital Commons. It has been accepted for inclusion in Articles \& Book Chapters by an authorized administrator of Osgoode Digital Commons. 


\title{
BOOK REVIEW
}

\author{
THE THREE 'Rs': \\ READING/RORTY/RADICALLY
}

Contingency, IRONY, AND SOLIDARITy. By Richard Rorty. 1 Cambridge University Press. Pp. xvi, 201. \$34.50. Paperback, \$10.95.

\section{Reviewed by Allan C. Hutchinson ${ }^{2}$}

America's romance with democracy has always been more tepid than torrid. Although the Jeffersonian impulse ${ }^{3}$ has occasionally fired Americans' imaginations, it has had implications that are too wideranging and unsettling for their temperament. The moderate de Tocqueville has always been much more to their liking. Alternately suspicious and wishful in his allegiance to popular governance, de Tocqueville presented a vision of democracy that tried to balance popular participation and professional knowledge. ${ }^{4}$ Yet, a century and a half later, American society has not met even the ambivalent aspirations of the Tocquevillean democrat; they are honored more in their breach than in their realization. While the formal trappings of republican democracy increase, the real extent and degree of public participation in politics and government declines. Electoral apathy is the abiding norm and disaffection is acute among blue-collar workers and blacks. ${ }^{5}$ Politics has become a symbolic spectacle for the people rather than a substantive engagement by the people.

Nowhere is antipathy for popular participation more evident than in the modern entrenchment of law and courts at the heart of American politics. No longer acting as a Tocquevillean check on legislative enthusiasms, the judges have taken over the major responsibility for the nation's policymaking. Moreover, instead of chastising courts for their imperial presumption, commentators celebrate them as the preferred forum for democratic deliberation. ${ }^{6}$ The cool detachment of

1 Kenan Professor of Humanities, University of Virginia.

2 Professor of Law, Osgoode Hall Law School, York University, Toronto. I am grateful to Joel Bakan, Alan Hunt, Frank Michelman, and Martha Minow for their comments on an earlier draft and to Corinne Doan, John Stanton-Ife, and Carole Trussler for their help in completing the essay.

${ }^{3}$ See The Writings of Thomas Jefferson (A. Lipscomb \& A. Bergh eds. I939).

4 See A. DE TocQueville, Democracy in America (G. Lawrence trans. I969).

5 See J. Cohen \& J. Rogers, ON DEMocracy: Toward a Transformation of American SOCIETY $32-35$ (I983).

6 See R. DWorkin, a Matter of Principle (I985); L. Tribe, God Save this Honorable COURT (1985). 
philosophical reflection is thought more conducive to democratic wisdom than the heated contestability of popular debate. As such, legal philosophy has been trafficked as the opium of the democratic masses. In a telling metaphor, a leading theorist of judicial legitimacy lionizes judges as princes of law's empire and philosophers (like himself) as its seers and prophets. ${ }^{7}$ This is a debasement of the democratic ideal, not its apotheosis. Attempts to pass rule by judicial aristocracy off as a philosophical act of noblesse oblige exacerbates rather than ameliorates the affront.

An unlikely and ironic source offers relief from this undemocratic state of affairs. While lawyers peddle traditional philosophy, the philosophical establishment itself is undergoing a serious crisis of confidence and is beginning to reassess its traditional self-image as a project of Truth-seeking. From within philosophy's own ranks, Richard Rorty has emerged as the most sophisticated and rigorous exponent of this critique. Now in self-imposed exile from the philosophical profession, ${ }^{8}$ he has incurred the wrath of many professional philosophers for his inspired, but disrespectful efforts to undermine and transform the epistemological foundations of their work. Over the past two decades, he has sought to demonstrate the contingent relation of language and philosophy - that the latest philosophical method offers not the final or privileged account of Truth, but one more vocabulary from an infinite possibility through which to understand the world. 9

Richard Rorty is an epistemological maverick. Primarily devoted to undermining the foundationalist ambitions of Western philosophy, Rorty's most influential work has rejected the notion that moral and social progress depend on finding the metaphysical bedrock of human existence. ${ }^{10}$ For Rorty, such excavations are futile and feckless; history goes all the way down. Philosophy is unavoidably situated in a historical framework. The question, then, of how we should live is not a methodological puzzle of abstract dimensions, but a substantive challenge of historical proportions. In pursuing this skeptical path, he chooses the historicist anti-heroes of modern philosophy - John Dewey, Ludwig Wittgenstein, and Martin Heidegger - as his heroic inspiration. As Rorty reads these writers, they hold that there is no

7 See R. Dworkin, LAw'S Empire 407 (1986).

8 Rorty left his position at Princeton's philosophy department, a bastion of hard-core analytic philosophers such as Saul Kripke and David Lewis, to become a Professor of Humanities at the University of Virginia.

${ }^{9}$ See R. Rorty, The Linguistic Turn: Recent Essays in Philosophical Method (I967); R. Rorty, Philosophy and the Mirror of Nature (1979) [hereinafter R. RoRTy, MirroR]; R. RoRTy, Consequences of Pragmatism (1982) [hereinafter R. RoRTY, ConseQUENCES].

10 See, e.g., T. NAGEL, The VIEW From NoWhere Io (1986); Moore, The Interpretive Tum in Modern Theory: A Turn for the Worse?, 4I STAN. L. REV. 87I (Ig8g). 
universal Truth nor suprahistorical Knowledge, but only an unbounded contingency:11 "we treat everything - our language, our conscience, our community - as a product of time and chance" ( $p$. 22, emphasis in original). For Rorty, the means to cope are not simply the best that we can hope for, but are all that we need or should want: the possibility of control is fanciful and far-fetched.

In his most recent offering, Contingency, irony, and solidarity, Rorty begins to pursue the political implications of his philosophical critique. He examines the following questions: can we give up on the idea of Truth and know what it means to be more or less free? In a society that accepts the contingency of everything, what institutional conditions best promote social justice? Does philosophical parochialism engender political resignation or revitalization? Contingency, irony, and solidarity reveals that Rorty's anti-foundationalism leads him to adopt a liberal approach toward these issues: he does not choose a conservative or radical affiliation. Not unexpectedly, Rorty champions democracy over philosophy: he gives short shrift to the false prophets of philosophical Truths. However, he is more a liberal than a democrat and less a Jeffersonian than a Tocquevillean. Although his radical philosophy sets him apart from the intellectual establishment, his liberal politics keep him squarely within it. He seeks "to retain Enlightenment liberalism while dropping Enlightenment rationalism" (p. 57). His commitment to democracy is conditional and circumscribed; the scope and depth of democratic governance is only warranted and supported in proportion to its capacity to enhance private autonomy and individual liberty. Although Rorty contends that philosophy must become more democratic, he ultimately concludes that democracy must remain in the service of liberalism.

That the philosopher of contingency should throw his theoretical weight behind a particular and contested form of politics is more than a little ironic. Nevertheless, Rorty's polished efforts to turn his philosophical insights to liberal advantage do not make his conclusions irresistible. To embrace Rorty's generally skeptical attitude toward the theoretical enterprise at large is not to talk or write as he does, nor to settle on the same political conclusions: that is the empty compliment of the epigone. Consequently, I do not take Rorty's vocabulary to be final or definitive, but treat it as one more contribution to the continuing conversation of humankind. Following the radical spirit rather than the liberal letter of Rorty's critique, his arguments are "better seen as another way of coping."12 Accordingly, I propose to read Rorty radically by concentrating on the democratic intimations

11 See, e.g., R. RoRTy, MirroR, supra note 9, at 9-ז3.

12 Id. at 356 (describing hermeneutics as "another way of coping," not "another way of knowing"). 
in his own text and by following the progressive leads that his critical inquiry turns up, but does not pursue. By taking the message of contingency more seriously than Rorty does, I intend to show the consonance of Rorty's non-foundational arguments to a more radically democratic political theory.

This essay centers on the three 'Rs' - Rorty, Reading, and Radicalism. I tell two different, but related and mutually reinforcing stories about the political and jurisprudential implications of Rorty's work. In the following Part, I explain and situate Rorty's attempts to debunk philosophy as a specialized body of knowledge and to inculcate a more democratic style of philosophizing. In Parts II and III, I explore the story of the limitations of Rorty's brand of liberalism and canvass the possibilities for a form of political practice and criticism that is more consistent with an uncompromising historicist critique. In Part IV, I consider the story of the implications of his arguments for legal interpretation and reasoning as particular and specialized types of "reading." Disagreements over the political ramifications of Rorty's non-foundational arguments have played themselves out in very different understandings of the judicial function. Indeed, Rorty's work has informed the debate between liberals and adherents of the Critical Legal Studies movement over the validity and status of legal practices. In response to those arguments, I extrapolate from Rorty's general propositions about argumentative techniques and offer a thoroughly democratic response to the dilemma of judicial legitimacy. By way of conclusion, I draw together the two stories and defend democracy as the Romantic expression of a poeticized politics.

\section{Philosophy Without Foundations}

In attempting to develop a practical means of "substitut[ing] Freedom for Truth as the goal of thinking and of social progress" (p. xiii), Contingency, irony, and solidarity has a threefold project. First, it offers a convenient occasion for Rorty to consolidate and summarize his skeptical critique of the persistent pretensions of contemporary philosophy. Second, and more interestingly, it takes up the considerable challenge of suggesting how to understand the "shift from epistemology to politics, from an explanation of the relation between 'reason' and reality to an explanation of how political freedom has changed our sense of what human inquiry is good for" (p. 68). Finally, Rorty explores what a non-foundational attitude to life and living means for individual lives and institutional arrangements. As such, Contingency, irony, and solidarity is a timely, weighty, and provocative undertaking.

For Rorty, modern philosophers would do well to develop a strong case of metaphysical vertigo. Their informing ambition is to rise 
above the phenomenal world of manifold appearances in the hope of locating some noumenal vantage point from which to gaze down upon the hidden, but essential, unity of the world and human history. ${ }^{13}$ In the metaphysical scheme of things, the validity of any claims about knowledge and reason depends upon philosophical inquiry being conducted at some distance from its own immediate historical and social context. Rorty wants to purge philosophy of these quasi-divinistic urges and "substitute the historicist metaphor of looking back on the past along a horizontal axis" (p. 96), but not as a prelude to viewing history as a repository of immutable verities. Rorty seeks to nurture a stronger sense of historical contingency so as to empower people rather than to cow them by the understanding that there are no antecedent truths or essential scripts to follow. By recognizing past truths as merely old contingencies, people can "get out from under inherited contingencies and make [their] own contingencies" (p. 97).

As an important part of his non-foundational project, Rorty recognizes and explores the profound connection between who people are and the communal language they speak (pp. I6-20). ${ }^{14}$ However, in keeping with his own recognition of inescapable contingency, Rorty does not view language as having an essential teleology or as a medium between mind and reality. For Rorty, the purpose of language is neither to represent an external reality nor express an internal essence. Each language has its own purpose and helps to constitute reality and minds in different ways. The world and individuals do not decide between competing languages because the world and individuals are not entirely separate from those languages. Rorty emphasizes that different languages are metaphoric creations that are contingently shaped. Like tools, languages remain in use because they offer functional advantages over any other vocabulary (pp. 9-20). The philosophic ambition ought not to be to assemble the perfect or complete linguistic tool box; it does not exist. To treat such a project as worthwhile or possible slips back into the old metaphysical habit of seeking to emulate science. Rorty suggests instead that the philosopher imitate the poet rather than the physicist. As there is only language with which to understand language, there is no nonreferential escape to "the way things really are." No form of life stands

${ }^{13}$ See id. at $13 \mathrm{I}-64$.

14 The best-known non-foundationalist in law is Stanley Fish. See, e.g., S. FISH, DoING What Comes Naturally: Change, Rhetoric, and the Practice of Theory in Literary AND LEGAL STUDIES $342-47$ (I989). Fish insists not so much that there are no foundations, but that they are local and temporal; they are part of the very history and conventions that they are supposed to validate and make intelligible. However, unlike Rorty, Fish does not believe that any particular political consequences follow from the non-foundationalist position; he finds no connection between a theoretical stance on interpretation and the practical activity of actual interpretation. See id. at 323-35. 
apart from language to validate life or authenticate language. Relying on imagination, the philosopher should seek to poeticize, not rationalize, culture (p. 79).

In Rorty's scheme of things, notions of knowledge and truth are distinctly not what they used to be. Nevertheless, this denial of an absolute Truth does not commit him to solipsistic relativism. A nonmetaphysical theorist rather than an anti-metaphysical theorist, Rorty does not reject the possibility of rational choice per se, but he does abandon the belief that it can be rational in the sense of Right or Final. Instead, he argues that the rationality of linguistic arrangements can only be validated from within, and that nothing is lost by this acknowledgement. A desultory nihilism is the bête noire of an unabashed absolutism: they are the Siamese twins of metaphysics. ${ }^{15}$ Rorty rejects the assessment of language in terms of its representational or expressive adequacy.

For Rorty, pragmatism has an important political consequence: no comprehensive theory integrates individual fulfillment and social solidarity in a single vision. Although acknowledging the validity and incommensurability of these competing demands, he nevertheless maintains that practical steps can establish a livable mode of collective and individual existence. His proposals do not take the form of a political manifesto or program. Instead, he introduces the figure of the "liberal ironist": 16

15 Rorty's non-foundationalism rejects nihilism or relativism as much as absolutism; each suggests that truth and meaning can be understood apart from the customary and extant procedures of discursive justification. See Rorty, Solidarity or Objectivity?, in PosT-ANalytic PhILosopHy 5-7 (J. Rajchman \& C. West eds. I985). While the absolutist looks beyond society and its language to the imagined nature of things, the relativist reduces knowledge to the private opinion of particular persons. The relativist adopts a correspondence theory of truth, but the pragmatic Rorty "does not have a theory of truth, much less a relativistic one." Id. at 6 . Some critics manage to ignore this crucial distinction. See Moore, supra note ro, at 892-905; Winter, Transcendental Nonsense, Metaphoric Reasoning and the Cognitive Stakes for Law, 137 U. PA. L. REV. IIO5, III7-29 (I989). As a pragmatist, Rorty treats the desire for objectivity as the wish for the greatest possible intersubjective agreement and human cooperation; "not having any epistemology, a fortiori he does not have a relativistic one." Rorty, supra, at 6 (emphasis in original).

Some who remain unpersuaded by this argument argue that the historicists' claim for the truth of their theory refutes itself because, contrary to their protestations, historicists do assume an absolute truth. See, e.g., H. ARKEs, First ThINGs: AN INQUiRY INTO THE First PRINCiples of Morals and Justice i32-33 (i986); J. Habermas, The Philosophical Discourse OF MODERNITY 96-97 (F. Lawrence trans. I987). This response begs the very question to be answered. The charge that historicism is self-refuting presupposes the possibility of the objective foundations for judgment that historicism denies. Historicists like Rorty want to dispense with the vocabulary of accuracy and representation and replace it with standards of usefulness and acceptability. See R. RORTY, MIRRoR, supra note 9, at 357-94.

${ }^{16}$ Rorty's decision to place his theorizing under the rubric of 'liberalism' is philosophically confusing, but politically understandable. He rejects liberal methods of justification, but accepts the value of liberal institutions. See infra p. 564. Like many liberals, he wants to claim the 
[M]y definition of 'liberal' $\left[{ }^{17}\right]$. . . [includes] people who think that cruelty is the worst thing we do. I use 'ironist' to name the sort of person who faces up to the contingency of his or her own most central beliefs and desires - someone sufficiently historicist and nominalist to have abandoned the idea that those central beliefs and desires refer back to something beyond the reach of time and chance. Liberal ironists are people who include among these ungroundable desires their own hope that suffering will be diminished, that the humiliation of human beings by other human beings may cease (p. xv).

Rorty maintains that no neutral or noncircular argument can defend his hopes for a post-metaphysical culture of "liberal utopia" ( $p$. $\mathrm{xv);} \mathrm{traditional} \mathrm{philosophy} \mathrm{hinders} \mathrm{more} \mathrm{than} \mathrm{helps.} \mathrm{Moreover,}$ "[a]nybody who thinks that there are well-grounded theoretical answers to this sort of question . . . is still, in his heart, a theologian or a metaphysician" (p. xv). Consequently, Rorty prefers to connect such a political vision to a historical tradition that is constantly being made and re-made rather than to try to validate it through the establishment of the essential Nature or common Essence of humankind. $\mathrm{He}$ looks to literary genres to perform that task. Accordingly, he devotes a greater part of Contingency, irony, and solidarity to exploring the ideas of 'liberal' and 'irony' through refined and insightful readings of different novels.

In a world of incorrigible contingency, the ironic challenge is to proliferate the linguistic possibilities, not to reduce them by the attempted refinement of one meta-vocabulary. Romantic poets fully understood the ironic sense of life's metaphoric possibilities: they grasped that the most important task that they could do was "to sum up their life in [their] own terms" (p. 97). ${ }^{18}$ Whereas Nietzsche (pp. 98-102) and Heidegger (pp. I08-20) rejected the metaphysical pursuits

liberal turf for his own by dismissing all other liberals' views of what liberalism comprises and demands. See, e.g., infra p. 579. Nevertheless, notwithstanding his many disagreements with contemporary liberals, he does rely extensively on the familiar public/private distinction (pp. xiii-xvi, 194-98). The critical arguments against the validity and merit of this staple feature of liberalism are too well-known to warrant further rehearsal. See Hutchinson \& Petter, Private Rights/Public Wrongs: The Liberal Lie of the Charter, 38 U. TORONTO L.J. 278 (I988). However, Rorty does suggest that an ironic liberalism would be properly contingent. While enlightenment liberals reduce the public to the function and servant of the private, Rorty insists that "such opposites can be combined in a life but not synthesized in a theory" (p. r20). Nevertheless, he still insists that the private precedes the public and, therefore, deserves greater attention (pp. 194-95).

17 Rorty attributes his definition of 'liberal' to Judith Shklar (p. xv).

18 Much romantic imagery - the obsession "with climbing mountains" - is masculinist. Nevertheless, the romantic tradition can be salvaged. For instance, an incorporation of forgotten female poets, like Mary Lamb and Charlotte Smith, into the Romantic canon can help to transform it into an earthier, more democratic, but no less visionary genre. See Romanticism AND FEMinism (A. Mellor ed. r988). For a radical retrieval of Byron's genius, see M. Foot, The Politics of Paradise: A Vindication of Byron (I988). 
of traditional philosophy, they retained the need to strive for an apocalyptic break from the past. Whether in the form of Superman or Being, they craved "the ineffable and absolute sublimity of the Wholly Other" (p. Ior). Deep down, they were really metaphysicians in historicists' clothing: they wanted to find a final vocabulary that would have the last word in humanity's conversation with history. More like Proust (pp. I02-06) and Freud (pp. 30-40), Rorty strives for "an expanding repertoire of alternative descriptions rather than The One Right Description" (pp. 39-40) and celebrates Derrida's refusal "to play by the rules of someone else's final vocabulary" ( $p$. I33). ${ }^{19}$

In developing the liberal side of life, Rorty believes, like Wordsworth, that "suffering is permanent, obscure and dark, / And shares the nature of infinity." 20 His deepest hope is that "suffering will be diminished, [and] that the humiliation of human beings by other human beings may cease" (p. xv). On the one hand, he emphasizes "how our attempts at autonomy . . . may make us oblivious to the pain and humiliation we are causing" (p. I4I). Through a reading of Vladimir Nabokov's novels, Rorty shows how private obsessions can blind people to the suffering they cause or might otherwise notice in others; "there is no synthesis of ecstasy and kindness" (p. I60). On the other hand, he enlists the literature of George Orwell to illustrate how the worst form of humiliation consists in persuading people that they "no longer have a self to make sense of" (p. I79); I984 is a meditation "about torturing, not about being tortured" (p. I80). ${ }^{21}$

Rejecting the metaphysical notion that there is some essential quality of humanness that society must aim to express solidarity toward, Rorty argues that those with whom solidarity is expressed must be more local and immediate than humanity at large; salience and sameness are historically created facts, not a discoverable echo of the infinite. For Rorty, this recognition does not impair the "urging that we try to extend our sense of 'we' to people whom we have previously thought of as 'they"' (p. I92), but disengages its defense from philosophical presuppositions. The liberal should constantly watch for marginalized people and empathize with their plight. In this way, Rorty suggests, individuals can "create a more expansive sense of

19 Rorty chooses to concentrate on the later Derrida of The Postcard: From Socrates to FREUd AND BEXOND (A. Bass trans. I987), rather than on the earlier Derrida of MARGins of Philosophy (A. Bass trans. Ig82).

20 W. WORDSWORTH, THE BORDERERS act III, 11. r543-44, at 215 (R. Osborn ed. I982).

21 In epistemological terms, Rorty offers a very controversial reading of Orwell. For instance, Rorty suggests that Animal Farm is "a strategically placed lever, not a mirror" (p. 174). He claims that Orwell seeks alternative descriptions rather than absolute proofs; Orwell discredits totalitarianism not because of its distortion of "moral reality," but rather the disutility of "old political ideas" (p. 175). 
solidarity than they presently have" (p. I96). Rorty argues that liberal ethnocentrism is distinguished by its very distrust of ethnocentric excess: "it is the ethnocentrism of a 'we' ('we liberals') which is dedicated to enlarging itself, to creating an ever larger and more variegated ethnos" (p. I98).

In sketching an image of the liberal ironist, Rorty insists that "there is no bridge between [a private ethic of self-creation and a public ethic of mutual accommodation] provided by universally shared beliefs or desires" (p. 34). Every person must do the best that she can to make what she believes to be the best possible connection; public need has "no automatic priority" (p. I94) over private obsession. Although more self-conscious, intellectuals provide only one example of the constant renegotiation of self-identity through living life. Political progress is a matter of the accidental coalescence of ironic circumstance and liberal sensibility. Rorty believes that, by cultivating the collective and individual image of liberal irony, a historicist culture can fulfill the utopian responsibility of ensuring "an endless, proliferating realization of Freedom, rather than a convergence toward an already existing Truth" (p. xvi).

\section{DANGERous Liaisons}

\section{A. The ' $L$ ' Word}

In Contingency, irony, and solidarity, Rorty attempts to show what implications a nonmetaphysical outlook has for personal values and collective arrangements. In his philosophical analyses, Rorty has maintained that this abandonment of foundations requires a move away from scientific ideals toward a poetic conception of the theoretical endeavour. However, Rorty applies his philosophy to political theory and practice in a much less clear and much less radical way. Although he still has to work out the detailed consequences of his epistemology, he points in the direction of a post-metaphysical culture of "liberal utopia" (p. xv). In this and the following sections, I argue that Rorty's reading of contemporary history misdirects him from a radical democratic road to a liberally utopian path. Rorty both pursues an overly idealistic analysis to the exclusion of more materialistic concerns and fails to take seriously his own message of historical contingency. In contrast, I emphasize the democratic themes of that message - social responsibility and transformative possibilities over its author's more liberal rendition - ethnocentrism and individualism.

Having purged himself of metaphysical assumptions and ambitions, Rorty looks to the American tradition for political guidance. He rejects any notion of natural rights, collective consciousness, or utilitarian calculus. Instead, he throws in his nonmetaphysical lot 
with liberal democracy. In particular, he champions the work of John Rawls $^{22}$ - of course, on pragmatic, not metaphysical grounds. For Rorty, Rawls does not offer a transhistorical template for liberalism, but treats liberal institutions and, most importantly, liberal vocabulary as a contingent expression of society's best contemporary self-image. He writes that "[w] true to an order antecedent and given to us, but its congruence with our deeper understanding of ourselves and our aspirations, and our realization that, given our history and the traditions embedded in our public life, it is the most reasonable doctrine for us'" (p. 58). ${ }^{23}$ Rawls' strength lies precisely in what some of his critics most condemn him for - a historicist, antiuniversalist and non-foundationalist defense of liberal democracy. Rorty would perhaps think that the resemblance of Rawls' theory of justice to the Democratic Party platform of r964 deserves cautious support rather than hasty condemnation. ${ }^{24}$

Apart from an almost ritual reaffirmation of liberal institutions and practices, like a free press and free universities (pp. 66-67), Rorty gives few concrete illustrations of how liberalism might respond to the existence of patriarchy, racism, economic inequality, and the continual threat of nuclear holocaust and environmental destruction. Consumed in his efforts to argue that liberal institutions can eradicate this cumulative state of affairs, Rorty fails to note that they have helped to create it. Rorty does, however, suggest that liberalism's private abhorrence of cruelty and its public commitment to toleration will make a difference - the best and only difference possible. Whatever a thoroughgoing historicism would make of Rorty's embrace of contemporary liberalism (pp. 35-48), his understanding of kindness and toleration has severe limitations.

Rorty's passionate account of cruelty and humiliation as "the worst thing we do" (p. xv) places too much emphasis on individuals and too little on structural arrangements. Collective practices can oppress or ennoble as much as can the isolated acts of well-intentioned individuals who live according to them and whose acts take on meaning within them. Although liberalism has eliminated much overt racism and sexism from public life, the institutions and practices that frame the ideas and activities of individual actors remain deeply and systemically flawed: the social whole is often greater than the sum of its

22 See Rorty, Thugs and Theorists: A Reply to Bernstein, I5 PoL. THEORY 564 (1987) [hereinafter Rorty, Thugs and Theorists]; Rorty, The Priority of Democracy to Philosophy, in The Virginia Statute for Religious Freedom 257, 264-68 (M. Peterson \& R. Vaughan eds. 1988) [hereinafter Rorty, Priority of Democracy].

23 Rorty quotes this passage from Rawls, Kantian Constructivism in Moral Theory, $77 \mathrm{~J}$. Pril. 5 I9 (I980), as representative of Rawls' position.

${ }^{24}$ See D. Lloyd \& M. Freemai, Lloyd's Introduction to Jurisprudence 4 16-20 (5th ed. 1985 ). 
individual parts. Discrimination is as much about the general effects of social practices as the intentions of individual actors. Individuals must go beyond good intentions to transform the political contexts that translate dominant interests into neutral standards, that turn momentary ideas into naturalistic assumptions, and that transform good intentions into bad effects. As Rorty overstates the matter, language and life are contingent expressions of particular ideologies and "[t]here is nothing to people except what has been socialized into them" (p. I77). By posing the problem in terms of individual action, liberals obscure as much as they explain and resolve particular instances of discrimination only at the expense of perpetuating its deeper effects and causes. Rorty's concentration on individuals' intentions rather than on the victims' conditions of life allows the "morally blameless" to wash their hands of the problem and makes it all too easy for liberals to "blame the victims." This liberal self-expiation obscures the uncomfortable fact that affirmative sacrifice by the dominant may be the only way to achieve substantial equality for the dominated. ${ }^{25}$

Rorty's discussion of the liberal need for public tolerance aggravates these flaws. The benign origins of Rorty's undoubted humanistic sentiments make their oppressive consequences no less troubling. Within an ethnocentric understanding of human solidarity (pp. I8998), the extension of conversational jurisdiction by "us" to "them" may be more an act of colonization than emancipation. This stance smacks of Liberal Man's Justice - the bringing of liberal civilization to ungrateful and recalcitrant tribes of illiberals:

Some victims of cruelty, people who are suffering, do not have much in the way of language. That is why there is no such thing as the "voice of the oppressed" or the "language of the victims." The language the victims once used is not working anymore, and they are suffering too much to put new words together. So the job of putting their situation into language is going to have to be done for them by somebody else. The liberal novelist, poet, or journalist is good at that (p. 94).

The spirit of Rorty's ironic liberalism clashes with the theme of the preceding passage. "We" do not impose social solidarity on "them"; instead, "we" and "they" effect it by opening "ourselves"/"themselves" up to the voice of the other and by our willingness to become a new "us"/"them." After all, "they" are another "us" and "we" are another "them" from the point of view of "them." The democrat does not seek

25 See D. Bell, AND We ARe Not Saved: The Elusive Quest for Raclal Justice (1987); Freeman, Legitimizing Racial Discrimination Through Antidiscrimination Law: A Critical Review of Supreme Court Doctrine, 62 MinN. L. REv. 1049 (1978); Singer, The Player and the Cards: Nihilism and Legal Theory, 94 YALE L.J. I, 4I-43 (I984). 
to empower the dominated with the voice of the dominant, but to open up the dominant discourse to the transformative voice of the dominated. ${ }^{26}$ To do otherwise is a supreme act of intolerance and condescension whose real identity as co-optation and conquest cannot be disguised in the liberal's colors of tolerance. A genuine commitment to liberalism's touted virtue of toleration demands that liberals prepare to forsake much of their own liberalism.

\section{B. The Unbearable Lightness of Being Rorty}

For all his efforts to demystify philosophy and to purge it of metaphysical pretensions, Rorty fails to take seriously his historicist insight. His exhortations that we recognize the pervasive presence of contingency conflict with his espousal of American liberalism. If "to fail as a human being . . . is to execute a previously prepared program" (p. 28), Rorty courts failure by submitting to the language of others. In political matters, he implicitly admits defeat in the poetic challenge of greatness and is "doomed to spend [his] conscious [life] trying to escape from contingency rather than, like the strong poet, acknowledging and appropriating contingency" (p. 28). An ironic liberalism assumes a tired, if reluctant, resignation to a reformed status quo: it leaves dominant and often oppressive institutional arrangements unchanged and seemingly unchallengeable. Liberalism seems the last refuge of the ironic scoundrel and the weak poet. At least, the metaphysical liberal strives to satisfy some deeper yearning, even if ultimately misguided and forever elusive. Paradoxically, Rorty, as the champion of liberal irony, seems both too liberal and not ironic enough for his own political good.

In short, Rorty puts the history back into philosophy, only to leave the politics out of history. He attempts to produce an apolitical vision of history in the name of a historicist philosophy. ${ }^{27} \mathrm{He}$ calls his philosophical knights home from the futile search for the epistemological holy grail. Rather than deploy them in the political struggle for social justice, he retires them to a rest home and leaves domestic politics as they are. In so doing, he denies, not celebrates, contingency. Championing liberalism evinces a profound failure to accept the contingent relation between philosophy and politics. Rorty's im-

${ }^{26}$ For an excellent treatment of this theme, see Minow, The Supreme Court, 1986 Term Foreword: Justice Engendered, IoI HARv. L. REv. Io (x987) [hereinafter Minow, Justice Engendered]. Rorty's Nietzschean aside - that "[d]emocracy is Christianity made natural" (p. 87, quoting F. NiETzSChe, Wirl to Power No. 215, at 126 (W. Kaufman ed. 1967)) illustrates in an enigmatic and troubling way his tendency toward intellectual imperialism.

27 For similar observations, see West, The Politics of American Neo-Pragmatism, in PostANAlytic Philosophy, cited above in note 15, at 259; and Comay, Interrupting the Conversation: Notes on Rorty, in ANTI-Foundationalism and PRACTICAL REasoning 83 (E. Simpson ed. 1987 ). 
plicit attachment to an ahistoricist vision of politics is evident throughout Contingency, irony, and solidarity. His fundamental concern to nurture "an expanding repertoire of alternative descriptions rather than The One Right Description" (pp. 39-40) is very idealistic in tone and application: little weight is given to material circumstances that constrain and inform efforts at linguistic redescription. Failure to appreciate adequately the grubby, materialistic and collective conditions under which "private attempts at self creation" (p. I94) take place make Rorty's notion of political struggle too clinical, intellectual, and individualistic. Rorty's political action is too much an armchair exercise. Urging the vita contemplativa has a cloistered tone that substitutes aesthetic appreciation for political struggle. He runs the real risk of pretending that simply reading the right books will make the world a better place. Of course, reading and writing are not irrelevant to changing the world, but they are insufficient in themselves. Although he claims to give equal weight to the demands of self-creation and of human solidarity ( $\mathrm{p} . \mathrm{xv}$ ), the text repeatedly confirms his quintessentially liberal instinct to give ontological and ideological priority to the pre-public and private individual and his or her personal efforts at recreation. Self-creation becomes the engine and energy of social change. Social solidarity becomes a serendipitous consequence of historical happenstance.

For example, Rorty commends Derrida for his prodigious work as a deconstructive poet. He sees Derrida's importance not so much in providing an alternative to philosophy, but in redescribing it in a playful, fantastical, and lubricous way and refusing "to play by the rules of someone else's final vocabulary" (p. r33). The point, although well taken, ignores the political ramifications of Derrida's work, and places the emphasis, and approbation, entirely on the private side of the ledger. A major ambition of deconstruction is the decentering of the individual in the public scheme of things.

Rorty further reveals his hand when he installs literary critics as "moral advisers" because "they have read more books and are thus in a better position not to get trapped in the vocabulary of any single book" (pp. 80-8I). He consistently promotes the bookish life as the best way to change and fulfill oneself (p. I4I). When 25 million Americans cannot read the warnings on products and an additional 35 million are functionally illiterate, ${ }^{28}$ the suggestion that books are the best road to salvation is pretentious. Rorty's conclusions that, except for Nabokov's special sensitivity, "we would not read him as often as we do" (p. I56) or that "Lolita and Pale Fire will survive as

28 See J. Kozol, Illiterate AMerica 4 (1985). Considering its socioeconomic status, the United States ranks an embarrassing 49 th among 158 U.N. member states in general literacy levels. See id. at 5 . 
long as there are gifted, obsessive readers" (p. I69) is too precious by far. Like many defenses of liberalism, it rests on a overly aristocratic and privatized view of society and social change. Rather than encouraging the "gifted" to read more books, Rorty should chide them into using their gifts in programs to reduce illiteracy and improve education.

Rorty's constant reminder to indulge "the spirit of playfulness" (p. 39) suggests an implicit reliance on an unbearable lightness of being. For all his vaunted situational embeddedness and historical contingency, he floats free of politics and shirks the heaviness of socialhistorical context. ${ }^{29} \mathrm{He}$ cannot detach himself from the deep metaphysical belief that the world of ideas is prior to and largely constitutive of the material world: "the novel, the movie, and the TV program have come to gradually but steadily replace the sermon and the treatise as the principal vehicles of moral change and progress" (p. xvi). ${ }^{30}$ In the same way that the preacher, the philosopher or the judge never changed things alone, the novelist or docudramatist alone will not cause progress. Ideas must combine with a concrete context in order to derive and express meaning. Such an understanding of the relation between ideas and social circumstances makes a pure materialism as inappropriate and ineffective as an unadulterated idealism. Power and knowledge are inextricably linked and mutually reinforcing; each implies the possibilities and parameters of the other. Without a social account of oppression's workings, transformative action will have little chance of real success. In this sense, Rorty's assessment of Foucault's work as "pretty much useless when it comes to politics" (pp. 6I-69, 83) misses the mark. Despite Foucault's unrelenting skepticism toward global blueprints for social change, he passionately advocated localized interventions through small-scale organizations like rape-crisis centers, prison-visitor programs, and mental-health advocacy groups. Foucauldian politics seek to effect democratic transformation by "creating conditions that permit the [disaffected and disenfranchised] themselves to speak."31

29 As such, Rorty's books and ideas mirror much of the gendered history of sexual relations and reflect the relatively light or abstract nature of male commitment. See M. KUNDERA, THE Unbearable Lightness of BeING (1984); see also Rorty, Priority, supra note 22, at 272 ('[P]hilosophical superficiality and light-mindedness helps along the disenchantment of the world.").

30 I have found the attempt to use different media to communicate a critical message of contingency useful and important, see, e.g., A. Hutchinson, DwELling on THE THreshold: Critical Essays on Modern Legal Thought chs. I, 3 \& 8 (Ig88), but a change of medium alone will not suffice to effect change. Indeed, a delegation of moral authority to literary critics is ironic because many seem to abdicate any authority for everything. / See S. FiSH, supra nate I4 (arguing neither for a historical foundation nor for a nihilistic abyss, but only for a thoroughly rhetorical world).

31 M. Foucault, Language, Counter-Memory, Practice 206 (D. Bouchard ed. 1977). For developments of this proposal for localized politics, see A. Hutchinson, cited above in note 30 , at 287-92. 
We can only fully grasp life by living. We cannot complete this task outside of language, but we cannot accomplish it entirely through language. Although "the . . . ironist desperately needs to talk to other people" and to be "continually entering into erotic relationships with conversational interlocutors" (p. I86), she or he must be prepared to reach out and respond to the actual plight of the oppressed. Direct steps must be taken to empower and liberate the homeless and the malnourished. There must be talk and action; angst is not enough. T.S. Eliot notwithstanding, intellectuals commit the greatest treason when they succumb to the belief that the rightness of the reason is always more important than the rightness of the deed..$^{32}$ The privileged indulge in a quibbling about reasons that the needy or disadvantaged find a distraction - actions and results not only speak louder than reasons, but they often disclose the real reasons and their meanings.

This critique does not deny a role for intellectual activity in the struggle for social transformation. Intellectuals must cultivate a more modest understanding of the power of ideas and, therefore, their own sense of political importance. Criticism must become an instrument of struggle rather than a reactive reflection on that struggle. Accordingly, in place of a lightness of being, those committed to social change will choose to bear the full weight of their historical belonging. They will strive to develop a genuine sense of solidarity with the oppressed in the hope that everyone will partake in the fortunes, good and bad, of the community. Popular action has won more freedom and justice than has the publication of a book or the judgment of a court. Insofar as pamphlets and judgments contribute to political change, they do so in a more subordinate way than lawyers, liberals, or (some) radicals think. ${ }^{33}$ Those who march in the streets or parade in the malls are in the vanguard of social change: the well placed Reebok has more power than the finely turned legal opinion or literary tract. In short, the L-word must give way to the $\mathrm{D}$-force - a democratic devolution and a decentralization of popular power and authority.

\section{The CRITICAL INCH}

A possible radical re-reading of Rorty hinges on the problem of "critical stance." His central insight is that, although there is no

32 See T.S. Eliot, Murder in the Cathedral 44 (1935) ("The last temptation is the greatest treason / To do the right deed for the wrong reason.").

${ }^{33}$ For instance, the deprofessionalization and republicanization of the courts can only prepare for the transfer of power from elite forums of knowledge to more popular arenas of participatory action. See M. Tushnet, RED, White and BluE: A Critical Analysis of Constitutional LAW 132 ( 1988 ) (arguing that courts played a subordinate role in the struggle for civil rights); Hutchinson, Charter Litigation and Social Change: Legal Battles and Social Wars, in ChARTER Litigation 357-82 (R. Sharpe ed. I987). 
escape from history and language, both history and language are endlessly contingent. The difficulty is, however, that he never seems to balance properly the competing imperatives of situatedness and transformation. In matters of private perfection and self-creation, he gives too much play to the lightness of contingent renovation and not enough to the heaviness of historical fixity. He favors the existential loner over the collective consciousness and exaggerates the odds in favor of an idiosyncratic revolution. However, in matters of social justice and human solidarity, he allows the pressures of historical boundedness to squeeze out the possibilities of contingent transformation. He succumbs too easily to the convenient defense of a reformed status quo and dismisses too readily the potential for radical renewal. As a result, he produces the familiar liberal mix of private heroism and public fatalism, with its individualistic prescription for social change through personal betterment.

A less ambivalent critical stance encourages social and moral progress. The revolutionary and the reformist both evade critical responsibility: the former tends to apocalypse and the latter to apology. The responsible critic should cultivate "a touch of the apostolic."34 Although critics can never stand apart from their society, they need not abandon their critical calling to enlist in the ranks of prevailing orthodoxy; they see themselves more as agents provocateurs than as terrorists. More distanced than distant, they will measure critical distance in inches and, although they cannot divine Truth, they can tell hard truths. ${ }^{35}$ Rorty correctly explains that the critics cannot presume to speak in the name of Reason, History, or whatever Else. As Rorty implies more than iterates, they can and should resist oppression on behalf of ordinary people; they should foster an antagonism towards privilege rather than an attitude of alienated cynicism or resigned despair. Instead of searching for lasting answers, they should pose immediate and troubling questions.

Throughout his work, Rorty understands criticism as more a reflective meditation than a political activity. In the same way that he detaches his thoughts on personal salvation from the contextual constraints of their informing socioeconomic practices, so he resigns his ideas on those institutions to the almost practical inevitability of their continuing existence. Contemporary social conditions, much less determinate and more malleable than Rorty acknowledges, leave much more room for radical optimism and less for liberal complacency than Rorty allows. Along with hints in Rorty's own texts, this recognition encourages and supports a critical stance more sympathetic to the

${ }^{34}$ R. BOURne, The Radical WiLl 483 (O. Hansen ed. I977).

35 See M. Walzer, The Company of Critics: Social Criticism and Political Commitment in the Twentieth Century $4 \mathrm{r}$ (1988); see also J. Merod, The Political ReSPONSIBILITY OF THE CRITIC (I987). 
possibilities for democratic transfiguration. I take seriously the democratic implications of Rorty's belief that "the future [is] up for grabs" (p. I84) and that a critic can "manipulate the tensions within [our] own epoch in order to produce the beginnings of the next epoch" ( $p$. 50). I find these to comprise the true vocation of the ironic critic.

Rorty posits a political choice between universal tolerance or enlightened chauvinism. He prefers to give special significance to one's own community and its social practices rather than to feign a universal solidarity with all other communities as fellow members of the human race. Consequently, the critic should not speak "in the name of humanity against arbitrary and inhuman social restrictions," but should "protest[ in the name of the society itself against those aspects of the society which are unfaithful to its own self-image" (p. 60). The key question becomes how to identify that self-image on whose behalf ironic criticism can viably proceed. With almost no explanation, Rorty selects a Rawlsian liberalism. He offers no account of why that particular tradition in American life can make such automatic claims on the normative imagination and people's sense of political allegiance. Even among liberals, Rawls' ideas have not swept all before them: the competition to carry the liberal flame remains as fierce as ever. ${ }^{36}$ Rorty does not acknowledge the diffusion and variegation of American history and politics or their tradition of competing traditions. Like it or not, the KKK belongs to American tradition as much as the NAACP, the anti-abortion forces are as vocal as the pro-choice movement, the Moral Majority holds as much sway as the children of the sixties, and the economically disadvantaged far outnumber the privileged. ${ }^{37}$ Although some view the United States as the home of freedom, others see it as the source of military imperialism and crass commercialism.

Against this backdrop, I am not convinced that Rawlsian liberalism represents America's traditional self-image. The landscape of America is much more contested and scarred than Rorty concedes. Its inhabitants' aspirations fall well below even the limited horizons of John Rawls. For the past decade, the United States has thrilled to the conservative rhetoric of a Reaganite Republicanism and the Lword has become a word of derision. In his more lucid and less chauvinistic moments, Rorty has his doubts about the American Dream. ${ }^{38}$ Yet conservative dalliance does not destroy Rorty's, nor even more progressive, efforts to nudge society towards a more egalitarian vision of itself and its practices. Moreover, such a critical enterprise is not only consistent with Rorty's deeper ironic insights

36 See, e.g., READING RAwlS (N. Daniels ed. I975).

37 See J. CoHEN \& J. Rogers, supra note 5, at 24-32.

38 See R. RORTY, Consequences, supra note 9, at jo. 
and his commitment to contingency, but they demand and support it. Although private self-creation requires less poetic activity - "changing the way we talk, and thereby changing what we want to do and what we think we are" (p. 20) - the political realm requires more. The ironic critic is not a fair-weather or part-time poet.

Even if critics cannot speak in the name of Reason or Humanity, they need not celebrate the status quo or some reformist understanding of it. This counsel of quietism runs the risk of conferring moral authority on immoral regimes such as those of Nazi Germany, South Africa, and Cambodia. The historicist scheme of things does not dispense with the need for justification, but demands that its identity and nature be transformed and transformable. Such evaluative criteria and the ledge for critical observation derive from Rorty's notion of human personality as "a tissue of contingent relations, a web which stretches backward and forwards through past and future time [rather than] a formed, unified, present, self-contained substance, something capable of being seen steadily and whole" (p. 4r). This recognition provides the most fitting standard that any responsible critic could want or have, an ironic metewand against which to measure social arrangements and critical institutions and toward which to direct any future political action. It is a tool of political empowerment, not a weapon of complicity. In an artifactual world of historical contingency, critics can protest on behalf of and work towards only the understanding of "human life as the always incomplete, yet sometimes heroic, re-weaving of such [webs of contingent relations]" (p. 43).

This view resonates with Unger's project of constructive social theory. Where Rorty is content to be a moral poet, Unger insists upon Romantic poetry; Unger is Rorty's radical sibling in the family of ironic theorists. Although Unger aims "to redeem liberalism through more liberalism,"39 his radical program of empowered democracy differs greatly from Rorty's insipid support for liberal democracy. Unger seeks to complete the rebellion against the naturalistic fallacy - the confusion of accident with essence and contingency with necessity - and to effect an irrevocable emancipation from false necessity. He chastises modern liberals, like Rawls and Rorty, for falling victim to the expedient temptation to allow illusion to pass into prejudice and to confuse the accidents of current institutional arrangements with a necessary democratic ordering. Unlike them, he offers a potential program that remains true to the belief that "[n]othing succeeds like plasticity." 40

${ }^{39}$ R. Unger, False Necessity: Antinecessitarian Social Theory in the Service of RADICAL DEMOCRACY 6I3 (I987).

40 R. Unger, Social Theory: Its Situation and Its TasK I98 (1987). Unger unfortunately insists on describing his program of radical democracy as "superliberalism." See Unger, The Critical Legal Studies Movement, 99 HARv. L. REv. 561, 602 (1983). A great distance lies 
In a recent paper, written after Contingency, irony, and solidarity went to press, but before its publication, Rorty expressed doubts about the worth of Rawlsian liberalism as a deserving object of his political allegiance and ironic sensibilities. Although he still can "manage two cheers for America - even America under Reagan,"41 he remarks that "[t]he institutions that empowered our past (for example, inheritable private property) may strangle our future - with the poor and weak getting strangled first, as usual." $42 \mathrm{He}$ congratulates Unger for his refusal to succumb to the status quo and his hopeful efforts to reinvigorate political imagination and transformative will. In particular, Rorty begins to recognize that the failure of any social theory to be romantic - making moves in a game nobody yet knows how to play - cannot resist being "inevitably retrospective, and thus biased towards conservatism."43 In light of these revised opinions, the bulk of Rorty's politics and social theorizing in Contingency, irony, and solidarity seem distinctly unromantic and fearful. His tragic liberalism has gone far astray from its historicist promise of utopian possibility and democratic solidarity. To make good on the radical possibility of his non-foundational philosophy, Rorty must strike out in the direction of Romantic politics.

\section{A Pragmatic Posture}

\section{A. Judicial Deductions}

Like the law, jurisprudence is not an intellectual pursuit autonomous to itself. The contending positions in contemporary jurisprudence track and often derive from those on the larger political scene. Legal scholars take the hermeneutical stances that they do because of their prior and more fundamental political commitments: their point of entry (and exit) in the debate over the nature of legal reasoning is largely ideological in character and motivation. Because Rorty's pragmatic arguments have informed some of the leading interventions in the debate over the nature of legal reasoning, the tension between

between Unger's superliberalism and Rorty's liberalism. For my own critical assessment of Unger's Romantic offering, see Hutchinson, A Poetic Champion Composes, 39 U. Toronto L.J. (forthcoming I990).

${ }^{41}$ Rorty, Unger, Castoriadis, and the Romance of a National Future, 82 Nw. U.L. REv. 335, 343 (I988) [hereinafter Rorty, Unger].

${ }^{42}$ See id. at 345. In an earlier piece, Rorty dismisses Marxism "as an amiable, but fruitless, exercise in nostalgia," and he argues that there is "no more point in trying to rework a political vocabulary developed in the middle of the nineteenth century than in trying to rework one developed in the middle of the fourth century B.C." Rorty, Thugs and Theorists, supra note 22, at 57. The vocabulary of liberalism, however, is no less passé than that of Marxism and is arguably even older.

${ }^{43}$ Rorty, Unger, supra note $4 \mathrm{I}$, at 347 . 
liberal and more radical readings of his work has energized and defined much of contemporary jurisprudential exchange. Accordingly, I explore and play out the implications of my radical reading of Rorty for the enduring controversy over the democratic legitimacy of judicial decisionmaking.

The democratic status of judges has always been suspect. The fragility of their legitimacy arises not so much from their exercise of power, but more from the nagging doubts about the warrant under which they wield such authority. Lawyers must claim to speak and act in a voice other than their own; they must justify themselves by reference to an authority beyond themselves - the law. Of course, no self-respecting modern lawyer or legal theorist pretends that law is "a brooding omnipresence in the sky"44 that lends itself to formulaic application or provides robotic predictability. It is trite learning that legitimacy cannot be grounded in law as a sealed system of normative directives. We can never simply "follow the rules" because the question of the relevant and precise rule and what following it entails remains irresolvably contestable.

More a constructive activity than a given thing, law involves an inescapable dimension of human choice; policy drives legal interpretation as an exercise in operational logic. The mainstream jurist must demonstrate that, even if legal doctrine does not compel definite results, it places sufficient constraints on judges to save them (and us) from themselves or, at least, to justify placing our trust in them. The jurist asks: how can $I$, in matters of normative judgment, get beyond a discredited formalism, without turning law into an open forum of ideological debate?

Although Rorty does not deal directly with law and legal interpretation, his work pertains to the viability and character of the jurisprudential project of legitimating legal interpretation. However, his work sends out contradictory hints on the worth and possibility of legal interpretation in a democratic polity. At times, he seems to insist that the functioning of a liberal democracy requires the preservation of a strong and free judiciary (pp. 66-67, 84).45 At other times, he has little patience for the philosophical pretensions of lawyers and legal theorists. He chastises judges for employing, in a similar fashion to theologians, paradigmatic metaphysical methods (pp. 77-78). With the exception of these fragmentary and casual observations, Rorty offers little insight into his views on law.

However, I do not intend to remain agnostic on this crucial jurisprudential issue. Contrary to other commentators, I do not think

44 Southern Pacific Co. v. Jensen, 244 U.S. 205, 222 (IgI 7).

45 See also Rorty, Thugs and Theorists, supra note 22 , at 567,573 (suggesting that a free judiciary is a valuable component of a liberal democratic society). 
that Rorty's work can be relied upon to explain and justify the judicial task. The underlying tenor and overall drift of his argument counter the continuing efforts to defend the democratic legitimacy of judicial review. Rorty's ideas suggest that so long as philosophical justification legitimates the Supreme Court's power, the wrong-headed view of "democratic politics as subject to the jurisdiction of a philosophical tribunal" (pp. I96-97) will persist.

Legal theorists have learned well from their practicing colleagues. Dogmatism and intransigence help neither the jurisprudential campaign nor the forensic encounter. The ability to shift critical ground as the circumstances dictate marks both the deft legal theorist and the skilled advocate. Although alternative pleadings may work in litigation, they cripple in jurisprudential exchange. The defense of the legitimacy of adjudicative power has led to some subtle but substantive alterations in argumentative stance. Over the past decade, judicial apologetics have abandoned strong claims of objectivity in favor of more humble assertions of determinacy. Pragmatism is distinctly back in vogue. ${ }^{46}$ Moreover, it has combined its less ambitious methodological stance with a more forthright defense of judicial legitimacy in the name of substantive justice. Present attempts to explain and guide judicial decisionmaking belong to two general camps. A Practical group extols the virtues of law as a system of practical reasoning; a Progressive faction takes a more openly political approach.

\section{B. Practical Pretenses}

Embarrassed by the more extravagant conceits of their predecessors, the Practicals accept that a strong defense of judicial objectivity is doomed, and no longer perceive legal reasoning as deductive at heart. The best that can be hoped for, according to these jurists, is to view law as a gradual accretion of conventional wisdoms that, in the form of rules and principles, give determinate guidance to the judges. Legal interpretation becomes a specialized instance of practical reasoning: informality replaces formality as a descriptive and prescriptive account of adjudication. These Practicals find no single algorithm for decisionmaking, only a potpourri of methods that include "a concern for history and context; a desire to avoid abstracting away the human component in judicial decisionmaking; an appreciation of the complexity of life; some faith in dialogue and deliberation; a tolerance for ambiguity, accommodation, and tentativeness, but a

46 Oliver Wendell Holmes, Jr., originally introduced to jurisprudence the resort to pragmatism at the turn of the century. See Grey, Holmes and Legal Pragmatism, 4I STAN. L. Rev. 787 (1989). For an attempt to survey and synthesize the pragmatic tradition, see R. SUMmers, INSTRUMENTALISM AND AMERICAN LEGAL THEORY (I982). 
skepticism of rigid dichotomies; and an overall humility."47 For those trained in the law's grammar, the rich conventions and diverse practices of the law's constraining community are thought to provide authoritative answers to most of the legal questions that logic cannot answer. In this sense, judging is more a practiced craft than a drill in systematic reasoning, more like riding a bike than solving a mathematical equation. Instrumentality and situatedness are the watchwords of the pragmatic revival.

For Rorty, this Practical approach would no doubt improve upon more traditional understandings of legal reasoning. Although its advocates use studiedly ironic rhetoric, they make decidedly metaphysical claims on behalf of practical reason. The Practicals still want to claim that, while not a science, legal reasoning is a lot less contingent and a little more final than other normative vocabularies. ${ }^{48}$ In short, they fall into the error that Rorty would condemn as "just one more attempt to believe that some words are privileged over others by a power not ourselves" (p. I22). Neither deductive nor analogical in its pragmatic incarnation, law remains propositional. Insofar as it eschews dialectical argument, Practical legal reasoning bears the hallmark of metaphysics in that it comprises what Rorty would call a "diligent inquiry according to antecedently formulated criteria" (p. 77). In contrast to the true ironist, the Practical "thinks of dialectic as a species of rhetoric, which in turn is a shoddy substitute for logic" ( $p$. 78).

Rather than accept law as one more way of coping, the Practicals cannot resist the temptation to turn it into a way of knowing. They mistake consensus for neutrality and press practical reasoning into service in the formalist workhouse. Trying to make a theoretical method out of an experiential muddle, the Practicals want to practice practical reasoning in a nonpractical way. Their analysis almost exclusively concerns textual and argumentational matters. They pay little attention to the actual social context in which disputes arise or to the political consequences of decisions: an attachment to and immersion in the relevant doctrinal tradition satisfies the condition of

47 Farber \& Frickey, Practical Reason and the First Amendment, 34 UCLA L. REv. 1615, I646 (1987); see also Farber, Legal Pragmatism and the Constitution, 72 MINN. L. Rev. I33I (I988); S. BuRTon, AN InTRoduction to LAW aNd Legal Reasoning (a985); Burton, Law as Practical Reason, 62 S. CAL. L. REv. 745 (1989); Kronman, Living in the Law, 54 U. CHI. L. REv. 835 (1987); Posner, The Jurisprudence of Skepticism, 86 MICH. L. REv. 827 (1988); Wellman, Practical Reasoning and Judicial Justification: Toward an Adequate Theory, $57 \mathrm{U}$. COLO. L. REV. 45 (1985).

48 See, e.g., Posner, supra note 47, at 829, 889; Posner, Conventionalism: The Key to Law as an Autonomous Discipline?, 38 U. ToRonto L.J. 333, 335 (1987); Posner, The Decline of Law as an Autonomous Discipline: 1962-1987, 100 HARV. L. REv. 761, 777 (1987). 
situatedness. ${ }^{49}$ For the Practicals, law continues to serve as the principal discursive device for deciding who speaks when, in what voice, and with what authority. Their firm ambition remains "to strike bottom" and to build the legal enterprise on secure epistemological foundations. ${ }^{50}$ Indeed, contrary to their philosophical protestations, they are decidedly not pragmatists. For them, in contrast to what Rorty might conclude, "the chief instrument of cultural change" is not "a talent for speaking differently," but one "for arguing well" (p. 7).

For instance, although celebrating and espousing a pragmatic approach to legal reasoning, Posner remains adamant that, "even though interpretation is neither a logical nor a scientific process it yields true understandings in . . . most legal cases." 11 In those few hard cases that defy resolution by practical reason, he suggests a four-step procedure to guard against idiosyncratic findings. It involves a conceptual toing and froing between the case at hand and the extant legal materials with the aim of arriving at a decision that extends the law, but remains within its constraining orientation. 52 Similar to the neoformalistic approaches of earlier jurisprudence, this adjudicative technique bears a striking resemblance to the metaphysical paradigm of rationality:

Because metaphysicians believe that we already possess a lot of the "right" final vocabulary and merely need to think through its implications, they think of philosophical inquiry as a matter of spotting the relations between the various platitudes which provide contextual definitions of the terms of this vocabulary. So they think of refining or clarifying the use of terms as a matter of weaving these platitudes (or, as they would prefer to say, these intuitions) into a perspicuous system. . . The typical strategy of the metaphysician is to spot an apparent contradiction between two platitudes, two intuitively plausible propositions, and then propose a distinction which will resolve the contradiction. Metaphysicians then go on to embed this distinction within a network of associated distinctions ... which will take some of the strain off the initial distinction. This sort of theory construction is the same method used by judges to decide hard cases, and by theologians to interpret hard texts (p. 77).

${ }^{49}$ See, for instance, the purportedly pragmatic analysis of New York Times v. Sullivan, 376 U.S. 254 (I964), in Farber \& Frickey, cited above at note 47, at 1631-39.

50 See L. Wittgenstein, Preliminary Studies for the "Philosophical InvestigaTroNs" 24 (2d ed. 1969). For an exchange over the possibility of using Wittgenstein to ground the jurisprudential enterprise, see Langille, Revolution Without Foundations: The Grammar of Scepticism and Law, 33 MCGrLL L.J. 45I (I988); and Hutchinson, That's Just the Way It Is:

Langille on Law, 34 MCGrLL L.J. I45 (I989).

51 Posner, supra note 47 , at 889 (emphasis added).

52 See id. at 863. 


\section{Progressive Irony}

Another group of legal scholars offer'more ironic promise. The Progressives have given up the painful attempt to distinguish what goes on in court from what takes place in other arenas of political debate. For them, law provides another site for normative conversation and deliberative dialogue rather than a specialized contribution to that debate. ${ }^{53}$ Indeed, they accept that traditional lawyers and legal theorists resemble what Rorty calls "sophistical casuists" (p. 194 n.6) in the way they first "figure out what practices to adopt" and later adjust their more general definitions "to suit" (p. Ig6 n.6) those practices. For example, in a Rorty-inspired critique, Singer argues that the law is woefully indeterminate and cannot meet its own foundational standards of rationality, objectivity, and neutrality. In place of this traditional understanding, he proposes an expressive conception of legal reasoning that is more open and less determinative and that views "legal and moral questions as matters to be answered by experience, emotion, introspection, and conversation, rather than by logical proof." 54 In the hands of the Progressive, practical reasoning becomes a thoroughly political way of coping; it does not confuse consensus with neutrality. The criteria for good judging will cease to center on style and form, but will direct themselves to a decision's substance and consequences.

Stick has taken Singer to task for what he thinks is a misapplication of Rorty's arguments. He argues that Singer remains trapped within the very same metaphysical tradition that Rorty wants to escape. Because law cannot satisfy the dictates of a foundational rationality and objectivity, Singer argues that the search for legal certainty and knowledge should be abandoned. Stick argues that this "irrationalist" position is anti-metaphysical rather than nonmetaphysical under Rorty's scheme of classification. ${ }^{55}$ Stick contends that only an understanding of law's rationality as comprising shared criteria of

53 See, e.g., M. PERRy, Morality, Politics, ANd LAW (1988); Michelman, Law's Republic, 97 YALE L.J. I493 (I988) [hereinafter Michelman, Law's Republic]; Michelman, The Supreme Court, 1985 Term - Foreword: Traces of Self-Government, 100 HaRv. L. REv. 4 (1986) [hereinafter Michelman, Traces of Self-Government]; Minow, Interpreting Rights: An Essay for Robert Cover, 96 YALE L.J. 1860 (1987) [hereinafter Minow, Interpreting Rights]; Minow, Justice Engendered, supra note 26, I0; Singer, Legal Realism Now, 76 CALIF. L. REV. 465 (1988); Stick, Can Nihilism Be Pragmatic?, 100 HaRv. L. REv. 332 (1986).

Rorty uses the examples of abortion and capital punishment to demonstrate how philosophers have nothing less controversial to offer in such circumstances than nonphilosophers; "the large general principles wait patiently for the outcome, and then the crucial terms which they contain are redefined to accord with that outcome" (p. I95). Their resolution is a detailed and historical process.

54 Singer, supra note 25 , at 56 .

55 See supra p. 560. 
cooperation rather than abiding standards of suprahistorical origin can make possible knowledge of that rationality. In short, law, as a practical discourse, possesses its own internal grammar and "can proceed on the basis of shared standards of agreement . . . without having to demonstrate that the shared standards of agreement necessarily give a perfect reflection of what is Really Out There."56

Stick properly criticizes Singer insofar as he proposes to hold law to external and foundational criteria of rationality. But, if Stick suggests that the coherence theories of a Dworkin ${ }^{57}$ or the interpretive proposals of a Fiss ${ }^{58}$ represent examples of Rorty's preference for pragmatic reasoning, he is surely mistaken. These theories engage in precisely the kind of metaphysical argumentation that Rorty would reject (pp. 77-78). ${ }^{59}$ Their resort to the political values and understandings of a vague "community" in order to unify the floundering legal enterprise makes a barely disguised attempt to ground the legal enterprise in something inside or outside itself. Rorty specifically criticizes Dworkin's, and other metaphysical liberals', search for general principles (pp. 58-6I). He chastises Dworkin for his misguided efforts to ground law as an enterprise of general principles rather than as a "convention and anecdote." 60

Furthermore, Stick wrongly argues against Singer's proposal for edifying argument. Stick maintains that edifying argument is only appropriate to abnormal discourses, like philosophy, which react to more normal discourses, like law. As Rorty puts it, edification makes "sense only as a protest against attempts to close off conversation by proposals for universal commensuration through the hypostatization of some privileged set of descriptions." 61 Stick attempts to undercut Singer by arguing that:

${ }^{56}$ Stick, supra note 53, at 393. Stick might well find some support for his interpretation of Rorty in Contingency, irony, and solidarity, especially in Rorty's explication of his philosophical differences with Habermas (pp. 66-68). However, I maintain that Rorty's liberal asides about legal institutions conflict with the deeper democratic core of his arguments. See infra section II.B.

57 See R. DwORKIN, supra note 7, at 19-20, 225-75.

58 See Fiss, Objectivity and Interpretation, 34 STAN. L. REv. 739, 739-4I (I982).

${ }^{59}$ See supra pp. 558-60.

60 Rorty, Postmodernist Bourgeois Liberalism, in Hermeneutics AND PRAXIS 214, 215 (R. Hollinger ed. I985) (quoting R. DwORKIN, A MATTER of PRINCIPLe 220 (I985)). In his most recent contribution, Dworkin compounds the difficulties and remains firmly within the metaphysical paradigm. When general principles clash, he treats them as competitive, not contradictory, and effects a rational reconciliation. If this reconciliation is not possible, the judge "must decide which is superior in personal and political morality, and though others would decide differently, that in itself is no objection." Dworkin, supra note 7 , at 444 . Doctrinal constraint seems a thing of the past. See Hutchinson, The Last Emperor?, in READING Dworkin CRITICALLY (A. Hunt ed. forthcoming 1990).

61 R. RORTy, MIRRoR, supra note 9, at 377. Rorty does suggest that law is one of the normal discourses, "at least in the lower courts." R. RORTY, CONSEQueNCES, supra note 9, at 
Prominent among the normal discourses of everyday life is law. Although law sets rules that people are forced to follow, it does not set rules of rationality for other discourses to follow. An argument for edifying law, therefore, cannot use the same argument Rorty uses to advocate edifying philosophy. Moreover, Rorty is willing to dissolve philosophy as a discipline because he thinks its stated purpose, to serve as the master discourse and set the rules of rationality for all human culture, is unnecessary. The argument that law is unnecessary in the contemporary world is certainly different from Rorty's argument, and even more controversial. It is the political argument of anarchism, rather than the philosophical argument of pragmatism. ${ }^{62}$

Stick's attempts to downplay law's significance only serve as reminders of its hegemonic tendencies. In the constitutional experience of the United States, law has not only sought "to serve as a method of discourse," but has had considerable success at "set[ting] the rules of rationality for all culture." Singer and others like him do not think that "law is unnecessary in a contemporary world." Singer is no anarchist and does not want to vacate the courts, let alone dispense with law itself: he simply proposes to revise the prevailing conception of legal reasoning. Moreover, Singer wants to do so because the imperialistic ambitions of law "to close off a conversation" tend to precipitate the very state of affairs that Rorty struggles to avoid the "freezing-over of culture" and "the dehumanization of human beings." 63 In this sense, Rorty might prefer Singer's expressive conception of legal reasoning to Stick's version of pragmatic reasoning.

Stick correctly points out, however, that any radical analysis of legal reasoning must go beyond methodological skirmishing to situate its epistemological challenge within a broader political critique of law. The best Progressives meet exactly this challenge. Taking an optimistic view of the courts' capacity to transform society and courts' own self-image, Progressives propose a style and standard of judicial performance that accepts the Supreme Court as "an organ of politics." 64 A proper understanding of democracy as a substantive and practical mode of constitutional organization and social life empowers, not disempowers, judges. Enjoying "a situational advantage over the people at large in listening for voices from the margins, "65 the courts act as conversational partners in achieving liberty and justice in the

xli. Stick notices this suggestion but fails to draw the obvious inference that normal discourse does not take place in those appellate courts that dictate the terms for discourse in lower courts. See Stick, supra note 53, at 389 n.244.

62 Stick, supra note 53 , at 389 . Like his Practical colleagues, Stick gives a very nonpragmatic exposition and defense of pragmatism. His typically abstract piece of legal theorizing never actually consults or tangles with the day-to-day practice of legal reasoning.

${ }^{63}$ R. RORTY, MirRor, supra note 9, at 377.

${ }^{64}$ Michelman, Law's Republic, supra note 53, at 1498.

${ }^{65} \mathrm{Id}$. at 1537 . 
flawed actuality of modern republican politics. The Progressives justify and encourage judicial activism as a way of making the normative best of a bad constitutional job. The Emperor may be naked, but the Progressives do not recommend that the democratic jurists struggle to fashion more convincing outfits of methodological garments. Instead, they will disabuse the Emperor of his imperial pretensions and encourage him to be more thoroughly modern in style and effect.

As a spur to implementing this Progressive approach, Minow suggests that judges recognize their role as reality-brokers - their important function as major producers of the ontological frameworks that shape the taken-for-granted assumptions and hidden-value categories around which we organize, understand, and evaluate life. Law establishes the values and perspectives that constitute objectivity and lack of perspective. By recognizing their own situatedness and perspectival understanding, judges might abandon the illusion of neutrality and begin "to hear and understand contrasting points of view about the treatment of difference." 66 In this way, Minow envisages the courts as the crucial interpretive forum for a communal conversation in which the voices of the excluded can join and transform the dominant discourse. The reinvention of rights as tools to express and strengthen community rather than as weapons to exacerbate conflict and alienation provide the vehicle for such transformation. In a Rortyan reference, she claims that her interpretive approach "grounds rights in the processes of communication and meaning-making, rather than in abstract or enduring foundations."

The Progressives make a useful contribution to the larger campaign for improved social justice, but they leave too much untouched and run very high risks. In a sense, success would be their worst enemy. If the judicial form changes, but the substance of decisionmaking remains the same, they will make a bad job look good without altering its thorough badness. Admittedly, a transformation in argumentative style might produce greater candor, but it has no necessary implications for the results reached. Moreover, such a move might obstruct any real progress by obstructing or reducing the political pressure on other institutions more qualified and suited to effecting such substantive change. Although the Progressives might combine a transformation of adjudication with a proliferation of democratic dialogue in other institutional sites and practices, ${ }^{68}$ the continued attachment to courts as the best and primary forum for such engagements ultimately

${ }^{66}$ Minow, Justice Engendered, supra note 26 , at 57.

67 Minow, Interpreting Rights, supra note 53, at 1862.

68 See Michelman, Bringing the Law to Life: A Plea for Disenchantment, 74 CoRNell L. REv. 256, 263 ( 1989 ) ("[P]erhaps being ruled by values ascribed to us by the disciplined discourse of a legal-judicial professional community is the best we can prudently hope for."); Michelman, Law's Republic, supra note 53 , at $153 \mathrm{I}-32$. 
defeats itself. Jurisprudential good intentions pave the road to judicial tyranny. ${ }^{69}$ Progressives cannot justify their gamble that judges will take seriously the idea of dialogic constitutionalism and act upon the vocal challenge of previously excluded perspectives rather than use it as one more device to reinforce and legitimate the illusion of a privileged reality and vision of justice. Democracy unqualified prefers to dethrone the Emperor than to attempt a wishful re-education.

The Progressives retain a naive faith that argumentative style is more important than the arguer's identity. They implicitly assume that which they chastise in others. Judges decide as they presently do in large part because of their normative instincts and political assumptions. The intellectual act of making these more visible and self-conscious will not by itself change the decisions reached. Although the unveiling of these assumptions might spur greater reflection and motivate an occasional change of heart, most judges will validate and ratify their informing visions; they decide as they do because of, not in spite of, their instincts and assumptions. Little suggests that the adoption of the Progressives' conversational proposals, unless accompanied by substantial reconstruction of socioeconomic conditions, will usher in a fresh era of egalitarian justice. Without such substantive reform, they will bring only judicial chatter rather than democratic dialogue to the political table. ${ }^{70}$

The truncated dialogue of adjudication will always be dominated by lawyers and operate within a framework of institutional and normative violence. Ordinary people do not take part in "jurisgenerative politics"71 and, therefore, never have the democratic opportunity to speak for themselves. Lawyers, as an elite class, embody a particular vision of society; they are predominantly white, male, and middleclass. Unless the sociocultural identity and political backgrounds of those appointed to judicial office dramatically shifts, the law will remain "a body of practices observed and ideas received over time by a caste of lawyers."72 To change this situation requires not only the agential endeavor of recruiting more representative judicial personnel, but also the structural challenge of transforming existing social and

${ }^{69}$ See J. Boswell, Life of Johnson 624 (R. Chapman ed. 1970). To use the courts as a venue for transformative action would require more disruptive and activist tactics than the Progressives seem prepared to countenance. They seem committed to a very familiar style of argument and advocacy. For a different approach, see Gabel \& Harris, Building Power and Breaking Images: Critical Legal Theory and the Practice of Law, II N.Y.U. REv. L. \& Soc. Change 369 (I982-I983).

70 See Hutchinson, Giving a Voice: An Essay in Dialogic Democracy, I YALE J.L. \& LIBERATION (forthcoming 1990); J. Bakan, Partiality and Legitimacy in Constitutional Theory (Nov. 9, 1988) (unpublished manuscript on file at the Harvard Law School Library).

71 See Michelman, Law's Republic, supra note 53, at I506.

72 Simpson, The Common Law and Legal Theory, in Legal Theory and Common Law 8, 20 (W. Twining ed. I986). 
economic conditions. Presumably, the compulsion to make the judiciary more representative by appointing more women and minorities implicitly recognizes that identity is more important than argument. Despite the laudability of this objective, these representatives will come from the lawyers' ranks and speak in the law's ideolect; therefore, a truly representative judiciary in terms of social and economic status will remain a contradiction in democratic terms. The appointment of a truly diverse judiciary can only occur after a dramatic change in the political structure and substance of society. Such a change would make the need for an activist judiciary no longer obvious or compelling. This conclusion reinforces the more general observation that judicial activity and interpretation largely, although not exclusively, depends on the larger economic and political forces at play in society.

In adopting this stance, I am not a "disappointed absolutist," and do believe that a sustained engagement in meaningful conversation can advance the democratic cause, and do not see a Hobson's choice between episodic judicial dialogue or endless shouting matches. Like Rorty and the Progressives, ${ }^{74} \mathrm{I}$ do not reject the possibility of reasoned argument, but the possibility that it can be rational in the sense of Right or Final. Practical reasoning is a necessary and desirable practice, but no democratic mandate requires the courts to be the most important institutional site for such practices: locus affects focus and interests shape identity. Law does the same for practical reason as philosophy does for reasoning at large; it attempts to turn it into a falsely privileged mode of discourse. Instead of increasing our efforts to make the courts republican, we would better spend our energy in proliferating the extra-curial sites and situations for the republican practices of engaged deliberation and genuine participation as economic equals. In this way, people might better develop the political sensibilities worthy of the truly democratic citizen - "a sense of the contingency of their language of moral deliberation, and thus of their consciences, and thus of their community" (p. 6I).

\section{A Democratic Romance}

When the French took to the barricades in the summer of 1789 , they sent shock waves through history that are still being felt all over the world. They did not storm the Bastille as an act performed in the name of Truth or Reason, but as a defiant struggle on behalf of

73 The term first appeared in H.L.A. HART, THE ConCEPT of LAW r35 (I96r). For a contemporary critique of Critical Legal Studies along Hart's lines, see Kress, Legal Indeterminacy, 77 CALIF. L. REv. 283, 329 (1989).

${ }^{74}$ See Michelman, Conceptions of Democracy in American Constitutional Argument: The Case of Pornography Regulation, 56 TENN. L. REv. 29I (1989). 
freedom and justice. The desire for "[l]iberté, [e]galité, [f]raternitê" often manifested itself in the excesses of bloody revolution and bitter revenge. That epochal occasion demonstrated that people need not endure history as irresistible fate, but could seize it and turn destiny to popular advantage. Not philosophers, preachers, or lawyers alone, but the courage and commitment of ordinary people made the improbable possible. The inarticulate gave expression to a romantic longing whose poetic embodiment continues to reverberate in the modern political consciousness. This supreme act of world-making and revolutionary poetry set the stage for modern history.

Rorty glimpses these truths, but a lack of democratic nerve stymies his political commitment. Although he puts "philosophy . . . in the service of democratic politics" (p. I96, emphasis in original), he still insists on putting democratic politics in the service of liberal ideology. To make good on the Deweyian, Jeffersonian, or Ungerian willingness to view social institutions "as experiments in cooperation rather than as attempts to embody a universal and ahistorical order," 75 Rorty must abandon his flagging enthusiasm for liberal democracy and replace it with a renewed dedication to unmodified democracy as the institutional and substantive setting par excellence for politics as experiment. This radical realization will not compromise his non-foundational beliefs, but will represent their full flowering. It offers Rorty the best way to enhance and transform the conversation of humankind and not simply to continue it. However, I do not propose strong democracy as a candidate to replace liberalism as America's natural self-image. Historicism eschews the belief in any single or accurate historical vision of community. Instead, I champion unreconstructed democracy because it provides the least worst match with the nonfoundationalist project for a truly pluralist polity. Furthermore, it can ensure that "transformative struggle" will change social conditions as well as the way we talk about them.

Democracy is the best hope that humankind has. It engenders self-knowledge and suggests the institutional arrangements indispensable to responsible and just lives. Its political dynamism provides the best available complement to historical contingency. Citizenship is not about meeting a begrudging obligation to an anonymous bureaucracy. In a truly democratic polity, it concerns the face-to-face, localized confrontations in conditions of economic equality that most promote personal empowerment and social solidarity. Not only intellectuals, but everyone, can have the opportunity to experiment as revolutionary poets and live in the "space open for the sense of won-

75 Rorty, Prionty of Democracy, supra note 22, at 274 . Rorty reiterates this radical commitment in urging that we have "faith in ourselves - in the utopian hope characteristic of a democratic community - rather than asking for reasons or back up from outside." Rorty, Education Without Dogma, r989 DisSENT 198, 201. 
der."76 Democracy understands that, for lasting and real change, people must combine efforts at personal transformation with those for public renovation; each depends on the other and neither can change alone. At bottom, the realization of radical democracy is probably a dream. But, like the best of dreams, it is an ironic awakening to life's poetic possibilities.

Not in Utopia, - subterranean fields, -

Or some secreted island, Heaven knows where!

But in the very world, which is the world

Of all of us, - the place where, in the end,

We find our happiness, or not at all! ${ }^{77}$

${ }^{76}$ R. RORTY, MIRRor, supra note 9, at 370 .

77 W. WORDSWORTh, THE PRELUde bk. XI, 11. I40-44 (I850). 